\title{
Modelling higher education financing reform for Ireland
}

\author{
Bruce Chapman $^{\mathrm{a}}$, Aedín Doris ${ }^{\mathrm{b}, *}$ \\ ${ }^{a}$ Research School of Economics, Australian National University, Canberra, Australia \\ ${ }^{\mathbf{b}}$ Department of Economics, Finance \& Accounting, Maynooth University - National University of Ireland Maynooth, Maynooth, Co. Kildare, Ireland
}

\section{A R T I C L E I N F O}

\section{JEL classification:}

I22

I28

H52

H81

Keywords:

Higher education finance

Ireland

Student loans

Income-contingent loans

\begin{abstract}
A B S T R A C T
This paper examines the feasibility of various alternative student loan schemes for Ireland. Using data from a large employer survey, we model the life-cycle earnings distribution for Irish graduates. We then use these estimates to simulate the effects of alternative types of student loans, including mortgage-type loans and incomecontingent loans of various designs, incorporating participation and migration patterns into the simulations. The results show that mortgage-type loans entail unsustainably high repayment rates for low income graduates. Through the specification of several alternative income-contingent loan schemes, it is demonstrated that this approach to higher education financing is feasible both in terms of affordability for graduates and with respect to implied government subsidies. There are some important policy design issues to be addressed and we conclude with some recommendations for a future Irish scheme.
\end{abstract}

\section{Introduction}

The Irish higher education system is currently financed by a combination of direct government funding and student fees. Unusually among OECD countries, the fee component is not accompanied by a student loan scheme, which has led to growing concerns about restrictions on access and hardship for students' families. Moreover, an increase in the fee level is being considered as a solution to substantial underfunding of the higher education system. In this context, the government is currently considering the introduction of a student loan scheme. The aim of this paper is to assess the feasibility of various alternative schemes in terms of concerns about both affordability for graduates and the consequences for public finances.

In conceptual and policy terms there is a consensus that government intervention is required in the financing of higher education. Such intervention can take the form of provision of a taxpayer funded system and/or government-backed student loans. Student loan schemes exist in many countries, and can be broadly broken into two types. The first entails a mortgage-type loan, which is either provided directly or guaranteed by the government, and has the main feature that graduates repay the amount borrowed over a fixed time period. An alternative approach is an income-contingent loan (ICL) system, which has been adopted in several countries as an alternative to mortgage-type loans. The critical feature of an ICL is that borrowers repay their debt only once their incomes surpass a given threshold, with the size and duration of repayments beyond this depending on the borrower's income.
Although student loans are available in many countries, there are several reasons for concern about the feasibility of introducing student loans in Ireland, and these are discussed in the context of the history and policy environment of Irish higher education funding in Section 2. Section 3 outlines the econometric approach taken to simulating the earnings distribution for Irish graduates; it also describes the data and reports the disaggregated estimations of life-cycle earnings profiles for Irish female and male graduates. These estimates are then used to simulate the effects of mortgage-type loan schemes on repayment burdens, with results being presented and discussed in Section 4. Section 5 uses the same estimated earnings profiles to simulate the likely collection experience of ICLs of various designs to illustrate the affordability of such approaches from the perspective of both graduates and public finance subsidies. Section 6 concludes.

\section{Irish higher education funding and the Irish policy context}

Before 1996, Irish university students paid tuition fees that were substantial relative to typical incomes at the time; in 1996, fees were about $€ 2000$ per annum at a time when average annual industrial earnings were about $€ 18,000$. These costs were mitigated by a system of 'student grants' that paid the fees (and some maintenance payments) for the children of families whose income was low enough to qualify. The proportion of university students in receipt of grants varied over the years, but an indicative figure is provided by McCoy, Calvert, Smyth, and Darmody (2009), who report that it was 63\% in 1992.

\footnotetext{
* Corresponding author.

E-mail address: Aedin.Doris@mu.ie (A. Doris).
} 
Student fees were abolished in 1996, at which point only a 'student contribution' of $€ 191$ was payable towards non-tuition costs such as examinations. The stated aim of this reform was to improve access to higher education for students from low income families. However, since such students already qualified for student grants, a positive effect seemed unlikely and in fact Denny (2014) found that the socio-economic gradient in higher education attendance was unaffected by the abolition of fees.

The student contribution was gradually increased over the years and by 2008 , it was $€ 900$. However, during and after the Great Recession in $2008 / 2009$, dramatic increases were imposed, with the contribution rising by $€ 500$ per year until it reached $€ 3000$ in 2014 . These fees are payable by about $50 \%$ of students, with the fees of those from lowincome backgrounds waived.

It is important to understand the economic background to this reversal away from 'free' higher education. Ireland was one of the countries worst affected by the Great Recession, with output falling by over $10 \%$ in real terms between 2008 and 2010 and unemployment rising from $5.0 \%$ in late 2007 to $13.2 \%$ in late 2009 , eventually peaking at $15.2 \%$ in early 2012 . The effects of the global recession felt elsewhere were compounded in Ireland by the bursting of a property bubble and the collapse of Irish banks, whose debts the government had earlier guaranteed. The government deficit rose from almost zero in 2008 to $13.9 \%$ in 2010 and a remarkable $30.8 \%$ in 2011, when banking losses crystallised. As a result, the government undertook a severe programme of austerity measures, combining tax increases and expenditure cuts.

The increased fee income from students allowed the government to reduce its expenditure on higher education during the years of most severe fiscal pressure. As well as transferring some of its expenditure on higher education to students themselves, the government also further reduced its funding of the sector at a time when student numbers increased substantially: between 2008 and 2015, total university income (including the increased student contribution) fell by $8 \%$ while student numbers rose by $14 \%$, leading to core income per student falling by $22 \%$. The state contribution fell by a remarkable $38.4 \%$ over this period. This sustained reduction in funding of higher education over several years has led to widespread recognition that funding must be increased if quality is not to deteriorate significantly (Expert Group, 2015).

Apart from increased funding per student being necessary, demographic patterns indicate that total funding would have to increase for many years to come even if funding per student were to be held constant: the number of students completing second level education is not projected to peak until 2029 , when there will be $27 \%$ more schoolleavers than there are at present. With a participation rate of 18-20 year olds in higher education of $58 \%$, such demographic growth clearly has significant implications for future funding needs if current participation rates are to be maintained.

Because of significant tax increases during the crisis, there is little political or popular enthusiasm for increased funding coming from general taxation. On the other hand, increasing the student contribution further under the current system is expected to be difficult. Although student grants - and a waiver of the student contribution - are available for about $50 \%$ of students, for the remainder, the fee component is already believed to be causing hardship for many families (Amárach Consulting, 2015). This hardship would clearly increase if the student contribution were to be increased. As a result, serious consideration is currently being given to the introduction of a system of student loans. The government appointed an Expert Group on the Future Funding of Higher Education, whose report recommended the introduction of an ICL system as one of three possible options (Expert Group, 2016). ${ }^{1}$

\footnotetext{
${ }^{1}$ The other options were a return to 'free fees' and the continuation of the
}

In the discussion of ICLs in Ireland, two main objections are commonly raised. First, because of the ongoing precarious position of the public finances, the possibility that a large proportion of the student loan book might not be repaid would be problematic. Moreover, the lag in repayments implied by a student loan scheme is of concern, given legal constraints on government borrowing implied by the EU Fiscal Treaty by which Ireland is bound. Second, the economic crisis is believed to have affected the young particularly badly, and the idea that young graduates would be further burdened with student debt is regarded by many as unfair. We detail these two concerns in turn below.

ICLs operate in several countries, including Australia, England, New Zealand and Hungary. In those countries, the size of the government subsidy varies widely across countries as well as over time. Shen and Ziderman (2009) report 'hidden grants' in these systems that vary from about $12 \%$ in the English scheme as it operated at the time to about 26\% in Australia; the reforms to the English system introduced in 2012 raised projections of the government subsidy to $43 \%$ according to Crawford, Crawford, and Jin (2014). Some of the subsidy arises because of interest charges being below the cost of government borrowing; this is a policy decision and can be controlled by policy makers to a large extent. The remainder of the subsidy arises from non-repayment of loans, which in turn arises because of graduates having low earnings and because of non-repayment by emigrants. These factors are less amenable to control by policy makers, and thus need to be assessed in advance of the introduction of an ICL.

There is good reason for concern about the possibility of high rates of non-repayment due to low earnings. A recent paper by Collins (2016) showed that $12.6 \%$ of employed Irish graduates are on 'low pay', defined as lower than a 'living wage' of $€ 11.45$ per hour. This may be explained by a particularly high level of over-education in Ireland: McGuinness, Bergin, and Whelan (2015) conclude that 33\% of graduates working full-time in Ireland are over-educated, the highest level of the 26 European countries included in their analysis, and significantly higher than the (unweighted) cross-country average of $18 \%$.

In addition to concern about low graduate pay, emigration is a particular concern in Ireland. Reports for recent cohorts of graduates indicate a high level of graduate emigration, with $12 \%$ of those graduating with primary degrees from Irish universities in 2013 working abroad nine months after graduating. This was a significant increase from the rate of $5 \%$ in 2006, but lower than the $17 \%$ recorded in 1986 , during the prolonged downturn of the 1980s (HEA, 2008; HEA, 2014). As regards broader graduate emigration, the OECD has estimated (Arslan et al., 2014) that the high-skilled emigration rate for Ireland is about $20 \%$, which is much higher than in the UK (11\%), New Zealand (9\%) or Australia (3\%), all countries for which graduate emigration has posed challenges for the implementation of ICLs. However, little is known about the duration of emigrating graduates' stays or the proportion that emigrate permanently, which makes it difficult to assess the implications of emigration for repayments.

As well as fiscal considerations regarding the introduction of an ICL, the effect on young graduates of loan repayments is a further important consideration. Many of the austerity measures introduced during the crisis period affected the young particularly strongly. The unemployment assistance payment was reduced for young claimants (aged 18-25) by over $50 \%$; these cuts were in addition to the general cuts to social welfare payments. Pay was cut by $10 \%$ for new entrants to public sector employment on top of substantial pay cuts that had already been applied to all public sector workers. A hiring ban was introduced in the public sector in order to reduce public sector employment, which particularly affected the employment opportunities of young graduates. As a result of these policy decisions, as well as the poor state of the labour market, starting salaries for graduates fell by almost $12 \%$ between their 
peak in 2007 and 2012, bringing salaries back to below 2004 levels (Conefrey \& Smith, 2014). In addition, unemployment rose from $8 \%$ to $29 \%$ for 20-24 year olds, the age group into which most new graduates fall. Emigration has also been substantial, with the European Commission (2013) estimating that the population of 15-24 year old Irish nationals fell by 9\% between 2007 and 2012 .

The effects of recent developments in the housing market on young people have also attracted much comment. In 2015, the Central Bank of Ireland introduced new mortgage rules that mean that first time buyers must save substantial deposits (10-20\% of the purchase price) before being able to buy. This coincided with a rapid increase in rents and wage stagnation, which has made such saving very difficult, and the public perception is that young people are being prevented from entering the property market. In a country that has traditionally had a high home-ownership rate - among Irish nationals, it is $74 \%$ - this is regarded as unfair. ${ }^{2}$

For all these reasons, particular attention must be paid to choosing scheme parameters that make repayments affordable to graduates while still yielding a reasonably high repayment rate to the government if a loan scheme is to be politically feasible in Ireland. Thus, one of the main aims of this paper is to compare mortgage-type loan and ICL schemes and to compare alternative parameters for these schemes.

There is one existing study that models an ICL for Ireland (Flannery \& O'Donoghue, 2011), comparing an ICL with a graduate tax from both fiscal and redistributional points of view. The methodology and data used differ from our analysis as the authors obtain their graduate earnings profiles from an Irish microsimulation model based on data from the Living in Ireland Survey, which was the Irish component of the European Community Household Panel (ECHP) that ran from 1994 to $2001 .^{3}$ The authors model an ICL scheme entailing a loan of $€ 10,000$ repaid at a rate of $10 \%$ on marginal earnings over a threshold of $€ 35,000$ and $15 \%$ for earnings over $€ 42,000$; they model two interest rate scenarios - one with a zero real rate, and another with a $2 \%$ real rate. Under this scheme design and assuming that emigrating graduates repay $40 \%$ of their debt, the average subsidy is $25 \%$ if a positive interest rate is charged, and $40 \%$ if not. The analysis of the repayment patterns of the graduates is somewhat unclear, however, with no explicit analysis of repayment burdens. In the analysis described in Section 5 below, we vary the parameters of the ICL loan scheme and pay particular attention to various measures of affordability as well as the size of the fiscal subsidy.

\section{Simulating the graduate earnings distribution}

To conduct the analysis of alternative schemes, we model life-cycle earnings across the Irish graduate earnings distribution using Unconditional Quantile Regression and 2006 data from the National Employment Survey (NES). The NES collects payroll records on earnings and hours of work from a large sample of firms with three or more employees. The sample is selected in proportion to the numbers of firms registered in each sector and size class (CSO, 2007). ${ }^{4}$ These payroll data are augmented with information on the personal characteristics of a sample of those employed by each of the surveyed firms. An advantage of the NES is the sample size: 67,700 employees in 4800 firms were

\footnotetext{
${ }^{2}$ An editorial in the Irish Independent newspaper ('Mortgage Rules are Very Unfair to Young People', March 2016) is typical of the media discussion of this point.

${ }^{3}$ Although the earnings projections are obtained from this micro-simulation model, labour market participation responses are not simulated.

${ }^{4}$ Although the CSO ensures that the firms sampled are representative in terms of sector and size class, no information is available on the proportion of employees excluded by the requirement to have at least three employees. CSO business demography figures indicate that approximately $20 \%$ of Irish employment is in enterprises with less than 10 employees, but more detailed breakdowns by firm size and graduate employment are not available.
}

surveyed, including about 8500 Irish graduates aged 25-55. A further advantage is the lack of measurement error in the earnings data. NES surveys were carried out in 2003, 2006 (twice) and annually from 2007 to 2009 , at which point they ceased because of government funding cutbacks. Thus, their disadvantage is that they are not current. ${ }^{5}$

We chose to use the 2006 data for our analysis for two reasons. First, data from 2008 and 2009 are likely to be unrepresentative of the Irish labour market, given that wage cuts were very common in those crisis years (Doris, O'Neill, \& Sweetman, 2015), particularly for older and better-paid workers. In the choice between 2006 and 2007, we took into account the evidence that mean starting graduate earnings in 2006 were closest to those in $2015 .{ }^{6}$ However, we acknowledge that even if mean starting salaries in 2006 and 2015 do turn out to be similar, the economic crisis may have caused permanent changes in remuneration patterns that resulted in permanent changes in the variance of graduate earnings and in life-cycle earnings profiles. For this reason, our estimates should be treated as indicative.

It is worth noting that there would be reasons for caution even if our data were very recent: simulations of lifecycle graduate earnings distributions that use cross-section data are based on the implicit assumption that future earnings of current cohorts will follow the same pattern as those of previous cohorts. However, as is well known from the literature on the labour market assimilation of immigrants (e.g. Borjas, 1985), predicting wage growth over time using a cross-section of workers may lead to biased estimates if the average quality of successive cohorts of workers is changing. If the ability levels of Irish graduates have been falling over time, this will lead to an upward bias in the slope of estimated age profiles.

It is plausible that the average ability of university graduates has decreased over time, since the proportion of 25-34 year olds in Ireland with a university-level qualification increased from about $14 \%$ in 1996 to about $40 \%$ in 2015 (OECD, 1998, 2016). Indeed, O'Connell, Clancy, and McCoy (2006) found that the prior academic achievement of HE entrants declined between 1998 and 2004, over which period the admission rate increased rapidly, from $44 \%$ to $55 \%$. On the other hand, OECD estimates of the internal rate of return to university-level education have shown the return increasing between 1994 and 2013 (OECD, 1997, 2017), ${ }^{7}$ which might not be expected if the average quality of graduates were declining. It may be that any bias generated by declining average ability is being offset by other features of the graduate labour market, in which case using cross-section data to estimate lifecycle earnings is reasonable.

To assess the effects of different loan arrangements, we need to estimate lifecycle earnings profiles at various parts of the distribution; this will be of particular importance for the welfare of those in the bottom parts of the graduate earnings distribution. The method usually used for estimating the effects of variables at points of the distribution other than the mean is quantile regression. Standard quantile regression estimates the effects of variables on the conditional distribution of the outcome variable, but this is not what is of interest here. Rather, we are interested in the effect of age on unconditional earnings.

\footnotetext{
${ }^{5}$ The most up-to-date Irish data set containing earnings data is the EU-SILC (Survey of Income and Living Conditions) and initially we attempted to conduct our analysis with these data. However, there were too few observations to estimate earnings profiles with any precision.

${ }^{6}$ Information on starting salaries is contained in annual surveys conducted by the Higher Education Authority. Conefrey and Smith (2014) use this information to calculate mean starting salaries for graduates in the years from 2004-2012 and report that the 2006 mean was just under $€ 26,000$, while the 2007 mean was about $€ 27,000$. The mean then fell in 2008 and 2009, settling at about $€ 24,000$ from 2009-2012. More recent HEA surveys indicate that starting salaries have been growing moderately since then (HEA, 2015, 2017). On this basis, we conclude that the mean starting salary in 2015 was close to that in 2006.

${ }^{7}$ From 14 to $21 \%$ for men and from 17 to $20 \%$ for women.
} 
Various methods have been used to 'back out' the unconditional effects. The method we use is one proposed by Firpo, Fortin, and Lemieux (2009) and used, for example, in Chapman and Liu (2013). This method transforms the dependent variable using a Re-centred Influence Function (RIF) transformation, and then regresses the transformed dependent variable on the independent variables using OLS. For the $\tau$ th quantile, $q_{\tau}$

$\operatorname{RIF}\left(Y ; q_{\tau}, F_{Y}\right)=q_{\tau}+\left(\tau-D\left(Y \leq q_{\tau}\right)\right) / f_{Y}\left(q_{\tau}\right)$

where $Y$ is income, $D$ is an indicator function, and $F_{Y}$ and $f_{Y}$ are the cumulative and marginal density functions respectively; the latter is estimated using the kernel density estimator. ${ }^{8}$

To model the distribution of earnings in sufficient detail, we estimate the relationship between age and earnings for 19 quantiles (from the 5th to the 95th) separately for men and women of Irish nationality aged 25-55. Descriptive statistics for the sample used are reported in Table A1 of Appendix A. The relationship between age and earnings is allowed to be fully flexible for each quantile; the final specifications vary between men and women and between quantiles. A quartic specification performs best for all quantiles of the female distribution up to the 85th, which probably reflects a reduction in hours worked during the child-rearing years. For men, a quartic specification is best up to the 35th quantile, but for higher quantiles, cubic and quadratic specifications are preferred. For each quantile, the parameter estimates are used to predict earnings at each year of age from 21 to 66 for each of the 19 quantiles, thus yielding a detailed picture of the entire distribution of life-cycle earnings. ${ }^{9}$

Once the quantiles of the lifetime earnings distribution have been simulated, annual productivity growth of $1 \%$ across the distribution is assumed, and the earnings profiles adjusted accordingly. This is similar to the $1.1 \%$ per annum baseline growth rate assumed for the UK in Crawford et al. (2014), but lower than the $2 \%$ per annum rate of productivity growth assumed in Flannery and O'Donoghue (2011) for Ireland.

The resulting simulated life-cycle earnings profiles for various quantiles of the distribution are shown in Fig. 1 for males and females respectively. These are the basis for the analysis in the remainder of the paper. A striking feature of these earnings profiles is the sharp reduction in earnings for most quantiles for ages beyond the late fifties for men, and beyond the early fifties for women. It is likely that these patterns reflect the labour supply behaviour of the particular cohorts of graduates of these ages rather than reductions in hourly wage rates, and given changes to pension arrangements in recent years, ${ }^{10}$ it is not clear that such patterns will apply to recent graduates. However, as the results below show, this is not of concern as the vast majority of graduates will have paid their loans off before reaching these ages.

\section{Results for Ireland: mortgage-type loans}

Mortgage-type loans would, if introduced in Ireland, allow the government to raise tuition fees while avoiding the negative effects on higher education access caused by up-front charges. However, repayment of mortgage-type loans can cause problems for borrowers, since repayments are based on time rather than capacity to pay and so are associated with both financial hardships and default risk. Default causes damage to a graduate's credit reputation and thus eligibility for other loans, such as for a home mortgage (Barr, 2001; Chapman, 2006). Repayment burdens (RBs), defined as the proportion of income

\footnotetext{
${ }^{8}$ The estimator is implemented using the rifreg command in Stata, provided by Firpo, Fortin, and Lemieux (2009).

${ }^{9}$ All regressions are weighted using the weights provided by the $\mathrm{CSO}$, which calibrate the survey responses to the totals from the Quarterly National Household Survey by sector, occupation, full/part-time status, age group and sex; see Central Statistics Office (2007).

${ }^{10}$ Defined benefit private sector pension schemes are now mostly closed to new entrants, and the age of entitlement to the state pension has increased from 65 to 66 and will increase further to 68 by 2028 .
}

accounted for by loan repayments, are the critical issue associated with mortgage-type loans because the higher is the proportion of a graduate's income that needs to be allocated to the repayment of a loan, the higher default probabilities and the more likely is repayment hardship. RBs for mortgage-type loans are unique for each individual borrower and can be well over $100 \%$ for very low income debtors.

In this section we discuss the RB results for mortgage-type loans of several specifications. The primary loan amount considered is $€ 16,000$. This is equivalent to $€ 4000$ per year for a four-year degree, which would entail a $€ 1000$ increase in annual fees from the current level. In fact, the Irish system includes both three and four year degrees for historical reasons, with about half of each intake of students undertaking four year degrees. ${ }^{11}$ However, accounting fully for different degree lengths in the analysis is not possible as it would require knowledge of where in the earnings distribution graduates with different degree lengths lie, which information is not available. To give an indication of the effect of a mortgage-type loan on graduates from three year degree programmes, we also provide analysis for a loan of $€ 12,000$. To assess the sensitivity of RBs to policy variables, we further allow repayment schedules to vary in terms of both the repayment start dates (two and five years after graduation) and loan term (10 and 15 years). In each case, the interest rate is set at a real rate of $2 \%$ per annum.

Table 1 provides mean and maximum RBs for working men and women and for the mortgage-type loan variations described above. In all variations analysed, the maximum $R B$ is the one that applies in the first year of repayments, while the mean $\mathrm{RB}$ is averaged over all years of repayments. The first panel of the table shows results for the base case. For both women and men, the average RB is particularly high for the bottom decile of the lifecycle earnings distribution, being between 20 and $23 \%$. Of particular concern are the maximum RBs that apply to the bottom three deciles; these are all greater than $20 \%$ and reach $83 \%$ for men in the bottom decile. The high RBs that apply to these lower deciles are clearly illustrated in Fig. 2 for men and women respectively. They show that while RBs for all workers - male and female - are below $10 \%$ by the 8th year of repayments, there is substantial variation in RBs in the 3-4 years after repayments start (5-6 years post-graduation). It is at this early stage in their working lives that graduates with mortgagetype loans are most vulnerable to hardship and default.

Of course, with a mortgage-type loan, the size of the loan is critical for the repayment burden, since the repayment period is fixed. RB figures for a $€ 12,000$ loan, shown in the second panel of Table 1 , are therefore uniformly lower than those for the higher loan amount. However, for the bottom decile, mean RBs are still over $15 \%$, while maximum RBs range from 54 to $62 \%$.

The third and fourth panels of Table 1 vary the repayment schedules of the mortgage-type loan. The third panel shows results for a 15 year repayment term, illustrating the extent to which spreading repayments over a longer period reduces RBs. The fourth panel shows that if the repayment start date is extended to five years after graduation, this also reduces RBs substantially. This is, of course, because of the steepness of the age-earnings profile in the early years of post-graduation work.

It is interesting to note that in each mortgage-type loan variation shown in Table 1, mean and maximum RBs are lower for women in the bottom half of the female lifecycle earnings distribution than for comparable men. This is due to the fact that earnings early in the lifecycle are typically higher for women, with correspondingly lower RBs. However, their age-earnings profiles are much flatter, so that by the end of the repayment period, the RBs women face are higher.

\footnotetext{
${ }^{11}$ Some degrees entail five and six years of study (for example, Medicine and Architecture), but the numbers are small. In addition, some students fail to progress at the end of some year of their degree, particularly at the end of the first year, and are required to repeat the year, which lengthens the time-todegree. Mooney, Patterson, O'Connor, and Chantler (2010) report that 3\% of students are repeating their year of study at any given point.
} 
Males

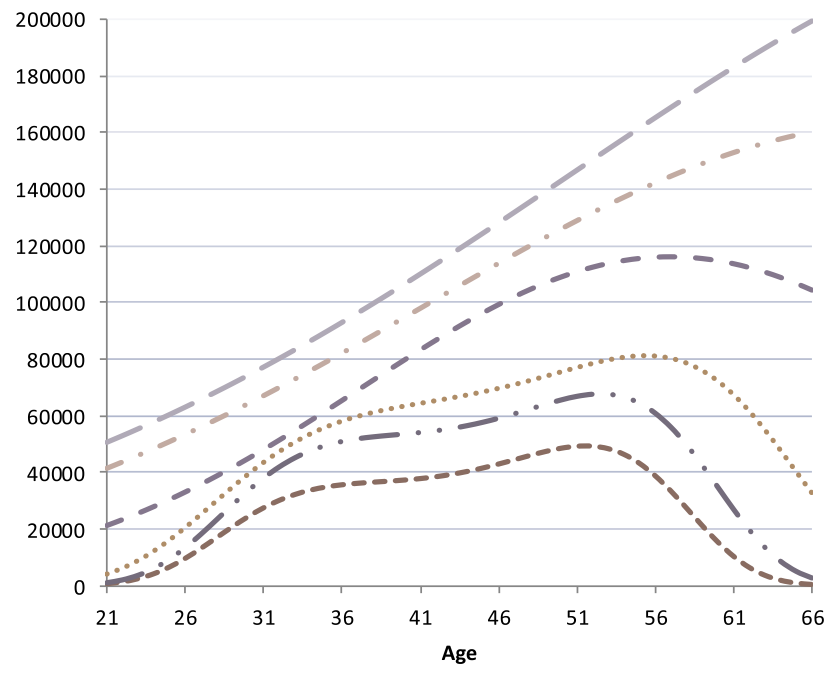

Females

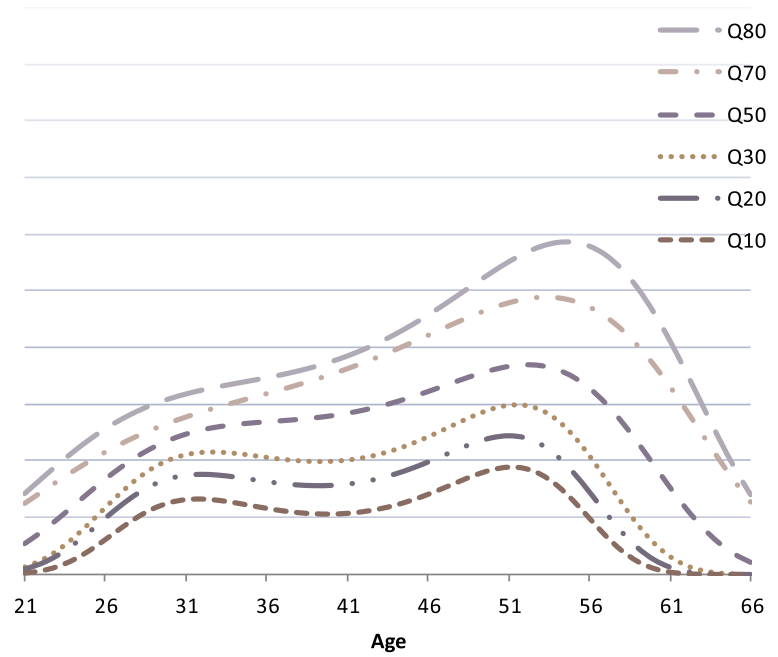

Fig. 1. Simulated life-cycle earnings profiles.

Table 1

Mortgage-type loan repayment burdens as percentage of net income, selected percentiles of lifecycle earnings distribution, varying terms and loan amounts, $2 \%$ real interest rate.

\begin{tabular}{|c|c|c|c|c|c|c|}
\hline & 10th & 20th & 30th & 50th & 70th & 80th \\
\hline & \multicolumn{6}{|c|}{$\begin{array}{l}\text { Base case: } € 16,000 \text { loan, } 10 \text { year term, repayments begin } 2 \text { years after } \\
\text { graduation }\end{array}$} \\
\hline \multicolumn{7}{|l|}{ Females } \\
\hline Mean & 20.0 & 11.2 & 9.4 & 6.5 & 5.4 & 4.8 \\
\hline Maximum & 72.7 & 29.9 & 23.6 & 10.7 & 7.3 & 6.6 \\
\hline \multicolumn{7}{|l|}{ Males } \\
\hline Mean & 23.4 & 16.3 & 9.7 & 6.3 & 4.6 & 4.1 \\
\hline Maximum & 82.6 & 53.7 & 22.1 & 8.8 & 5.8 & 5.1 \\
\hline
\end{tabular}

$\underline{€ 12,000}$ loan, 10 year term, repayments begin 2 years after graduation

\begin{tabular}{lllllll} 
Females & \multicolumn{7}{l}{ graduation } & & & & \\
Mean & 15.0 & 8.4 & 7.0 & 4.9 & 4.1 & 3.6 \\
Maximum & 54.5 & 22.4 & 17.7 & $\mathbf{8 . 0}$ & 5.5 & 4.9 \\
Males & & & & & & \\
Mean & 17.5 & 12.2 & 7.2 & 4.7 & 3.4 & 3.1 \\
Maximum & 62.0 & 40.2 & 16.6 & $\mathbf{6 . 6}$ & 4.3 & 3.8 \\
\hline
\end{tabular}

\begin{tabular}{|c|c|c|c|c|c|c|}
\hline \multirow[b]{2}{*}{ Females } & \multicolumn{6}{|c|}{$\begin{array}{l}€ 16,000 \text { loan, } \underline{15} \text { year term, repayments begin } 2 \text { years after } \\
\text { graduation }\end{array}$} \\
\hline & & & & & & \\
\hline Mean & 11.5 & 6.8 & 5.8 & 4.2 & 3.5 & 3.2 \\
\hline $\begin{array}{l}\text { Maximum } \\
\text { Males }\end{array}$ & 53.1 & 21.8 & 17.2 & 7.8 & 5.4 & 4.8 \\
\hline Mean & 12.7 & 9.0 & 5.7 & 4.0 & 3.0 & 2.7 \\
\hline Maximum & 60.3 & 39.2 & 16.2 & 6.4 & 4.2 & 3.7 \\
\hline
\end{tabular}

\begin{tabular}{|c|c|c|c|c|c|c|}
\hline \multirow[b]{2}{*}{ Females } & \multicolumn{6}{|c|}{$\begin{array}{l}€ 16,000 \text { loan, } 10 \text { year term, repayments begin } \underline{5 \text { years }} \text { after } \\
\text { graduation }\end{array}$} \\
\hline & & & & & & \\
\hline Mean & 10.0 & 7.6 & 6.6 & 5.7 & 5.1 & 4.6 \\
\hline Maximum & 17.1 & 11.1 & 10.1 & 7.6 & 6.4 & 5.7 \\
\hline \multicolumn{7}{|l|}{ Males } \\
\hline Mean & 10.4 & 8.0 & 6.7 & 5.7 & 4.4 & 3.9 \\
\hline Maximum & 21.9 & 15.8 & 10.8 & 7.6 & 5.5 & 4.9 \\
\hline
\end{tabular}

Median shown in bold.

We next estimate the proportion of graduates for whom the repayment burden is problematically high. Here, we adopt the Baum and Schwartz (2006) definition of an RB as 'excessively high' if it exceeds $18 \%$ of gross income. We assume that graduates must repay over a fixed time period, and are not allowed to defer repayments if they are not working. In order to implement this, we need to consider those who are not in employment, for whom RBs will obviously be excessive, as well as the RB figures for employees given in Table 1. We therefore calculate employment rates by year of age separately for male and female graduates using the EU-SILC data mentioned in Section 3 above. ${ }^{12}$ These employment rates are given in Table A2 of Appendix A.

The patterns shown in these employment data indicate that women have higher rates of participation than men when they are young, perhaps due to fewer women pursuing postgraduate study. However, 10 years after graduation, men's employment rates exceed women's and remain higher thereafter. Nevertheless, women's employment rates remain above $80 \%$ until women are aged 37 , at which stage they begin to drop steadily. It should be noted that using the employment rates of women currently aged over 40 is likely to underestimate the future employment levels of current university students if female participation rates continue to increase. However, it is employment rates at young ages that are of most concern in the present exercise, since this is when the bulk of repayments of student loans (whether a mortgage-type loan or an ICL) are made.

Adding the proportion of graduates not employed in the years during which repayments are required to the proportion of working graduates experiencing RBs of greater than $18 \%$ during those years yields the probabilities of excessively high RBs shown in Table 2.

The results of the first panel of Table 2 show that for the base case, in the first year in which repayments are due, a large majority of graduates $-70 \%$ of males and $67 \%$ of females - face excessively high RBs. Income growth ensures that this proportion falls in subsequent years but even after five years, over a quarter of graduates face such high RBs. Even if those not working are allowed to defer their loans, the proportion of graduates with excessively high RBs lies between 10 and $40 \%$ for women in the first three years of repayments, and between 20 and $35 \%$ for men in those years. It seems highly unlikely that these RBs would be seen as fair; moreover they imply the strong likelihood of many graduates experiencing consumption hardship, with a proportion of these being forced to default. The subsequent panels illustrate the effect of reducing the size of the loan, spreading repayments over more years, and delaying the start of repayments. Reflecting the results in Table 1, these policy choices do indeed mitigate the high RBs observed in the base case. Nevertheless, excessive RBs continue to be prevalent for a substantial minority even in these cases.

\footnotetext{
${ }^{12}$ Recall that the NES data cover employees only and so cannot be used to estimate employment rates.
} 
Males

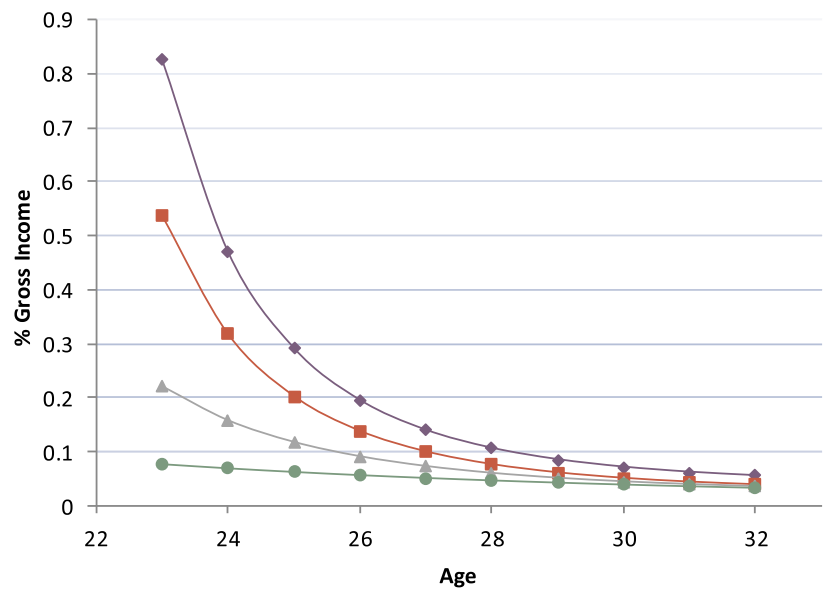

Females

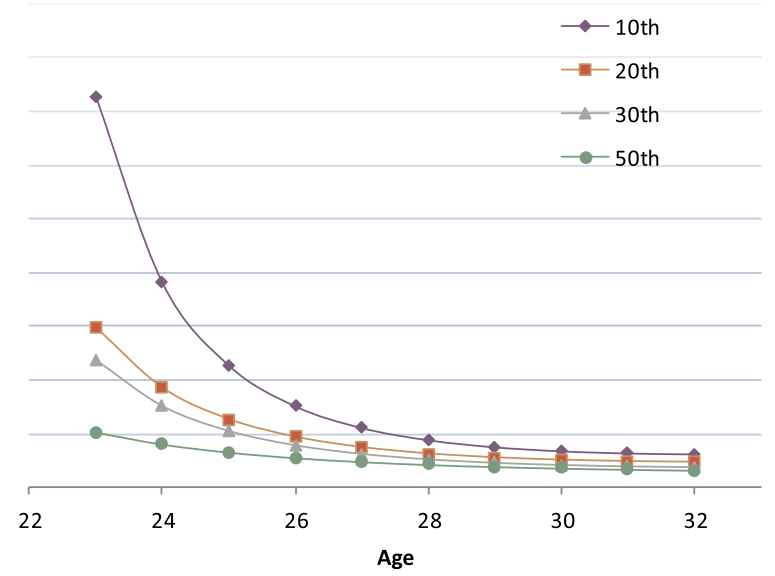

Fig. 2. Mortgage-type loan repayment burdens for employees, various quantiles of the earnings distribution, $€ 16,000$ loan, repayments begin 2 years after graduation.

Table 2

Probabilities of RBs in excess of $18 \%$ of gross income.

\begin{tabular}{|c|c|c|c|c|c|}
\hline & \multicolumn{5}{|c|}{ Years after repayments begin } \\
\hline & 1 & 2 & 3 & 5 & 10 \\
\hline & \multicolumn{5}{|c|}{$\begin{array}{l}\text { Base case: } € 16,000 \text { loan, } 10 \text { year term, repayments begin } 2 \text { years after } \\
\text { graduation }\end{array}$} \\
\hline Females & 0.67 & 0.43 & 0.27 & 0.25 & 0.15 \\
\hline \multirow[t]{2}{*}{ Males } & 0.70 & 0.60 & 0.43 & 0.28 & 0.12 \\
\hline & \multicolumn{5}{|c|}{$€ 12,000$ loan, 10 year term, repayments begin 2 years after graduation } \\
\hline Females & 0.57 & 0.33 & 0.22 & 0.25 & 0.15 \\
\hline \multirow[t]{2}{*}{ Males } & 0.70 & 0.60 & 0.38 & 0.28 & 0.12 \\
\hline & \multicolumn{5}{|c|}{$€ 16,000$ loan, 15 year term, repayments begin 2 years after graduation } \\
\hline Females & 0.57 & 0.33 & 0.22 & 0.25 & 0.15 \\
\hline \multirow[t]{2}{*}{ Males } & 0.65 & 0.55 & 0.38 & 0.23 & 0.12 \\
\hline & \multicolumn{5}{|c|}{$€ 16,000$ loan, 10 year term, repayments begin $\underline{5 \text { years }}$ after graduation } \\
\hline Females & 0.26 & 0.30 & 0.15 & 0.14 & 0.18 \\
\hline Males & 0.32 & 0.28 & 0.22 & 0.13 & 0.04 \\
\hline
\end{tabular}

\section{Results for Ireland: ICL}

Having established that a mortgage-type loan would entail RBs that are problematic for individual graduates, we now turn to modelling several alternative ICL schemes, which are designed to limit RBs to affordable levels. There are several parameters of ICL loan schemes that affect personal affordability and the size of the government subsidy. These include the earnings threshold; whether repayments are levied on total or marginal income once the threshold is reached; the rate(s) at which repayments are levied; what, if any, real interest rate is charged; whether the interest rate is charged in all years in which debt is held, only in post-graduation years, or only in years in which earnings exceed the threshold; and whether outstanding debts are written off at some age, typically 55 or 60 .

We experimented with a broad range of scheme parameters. It quickly became apparent that a relatively low earnings threshold should be used, as otherwise graduates in low earnings quantiles repay a very low proportion of their loans. The earnings threshold is therefore set at $€ 26,000 .{ }^{13}$ In addition, because of the shapes of the age-earnings profiles reported in Section 3, introducing a write-off age made no difference; loans had either been paid off by age 55, or earnings had fallen below the threshold at that stage.

When we experimented with a positive real interest rate of $2 \%$ charged in all years after graduation, repayments were found to be

\footnotetext{
13 This is the 2006 mean annual average starting salary in the HEA graduate earnings survey (HEA, 2008).
}

strongly regressive; those from higher earnings quantiles repaid less than those from lower earnings quantiles. This would be regarded as a very unattractive feature of an ICL scheme if introduced in Ireland, particularly considering the fact that students whose parents have low incomes pay no fees in the present Irish system, leading to strong progressivity in terms of parental income (but not necessarily graduate income). To avoid regressivity, we therefore model two alternative interest rate regimes, one entailing a zero real rate of interest, and the other rising to a $2 \%$ real rate of interest in periods when income rises above the $€ 26,000$ threshold, but zero otherwise; hence no interest is charged prior to graduation.

Two repayment schedules are modelled to reflect the variations that exist in countries that have ICL schemes. In most countries, collection is based on a marginal rate only on income above the earnings threshold; in contrast, the Australian system collects a percentage of total income once that threshold has been reached. Depending on the income bases used - whether marginal or total - the rates also differ. For example, in Australia, repayments are calculated as between 4 and $8 \%$ of total income, whereas in England and Wales, repayments are calculated as 9\% of marginal income and in New Zealand, the rate is $12 \%$ of marginal income.

The first repayment schedule modelled here entails a flat rate of $8 \%$ on marginal income above the threshold. The second entails rates of $2-8 \%$ on total income once the threshold is reached, starting at $2 \%$ and rising in increments of $1 \%$ for every $€ 5000$ of additional earnings over $€ 26,000$ up to $8 \%$ on earnings above $€ 56,000$. $^{14}$ The loan amount is

\footnotetext{
${ }^{14}$ To be precise, details of the two scheme types are as follows. For the scheme with repayments based on marginal income:

$R=\left\{\begin{array}{c}0.08(Y-26) \text { if } B \geq 0.08(Y-26) \text { and } Y>26 \\ B \text { if } B<0.08(Y-26) \text { and } Y>26 \\ 0 \text { if } Y \leq 26\end{array}\right.$

where $R$ is the annual repayment in thousands of euro, $Y$ is annual earnings in thousands of euro and $B$ is the size of the outstanding loan balance, also in thousands of euro. For the scheme with repayments based on total income:

$R=\left\{\begin{array}{c}(0.02+0.01 x) Y \text { if }(26+5 x)<Y \leq(31+5 x) \text { and } B \geq(0.02+0.01 x) Y \\ 0.08 Y \text { if } Y>56 \text { and } B \geq 0.08 Y \\ B \text { if } B<(0.02+0.01 x) Y \text { and }(26+5 x)<Y \leq(31+5 x) \\ B \text { if } B<0.08 Y \text { and } Y>56 \\ 0 \text { if } Y \leq 26\end{array}\right.$
}

for $x=0,1, \ldots, 5$. 
again assumed to be $€ 16,000^{15}$ and graduates are eligible to start repaying their loans immediately on graduation.

Tables 3 and 4 show results for working females and males respectively. The four panels of the tables apply to the four alternative specifications of the ICL scheme. The columns show the results for various quantiles of the distribution, with the column for median earnings highlighted in bold. The rows in each panel represent various indicators of affordability - absolute monthly and total repayments, repayments as a percentage of net earnings, and total repayments discounted at a rate of $2 \%$ per annum. Years of repayment and age of final repayment are also included to allow comparison with the mortgage-type loans discussed in Section 4 for which the years of repayment are set at 10 (or 15) and the age of final repayment for our hypothetical graduates is set at 32 (or 37).

For female workers, the proportion who pay off their loans in full depends on the particular scheme design; schemes with repayments that are based on marginal income generate a lower degree of full repayment, with the bottom $15 \%$ of lifecycle earners failing to pay in full, whereas the bottom $10 \%$ of earners fail to pay in full in schemes with repayments based on total income. For all schemes, the number of years for which repayments are made declines as the earnings quantile increases, so the higher the earnings, the more quickly and the earlier in life they are paid off in full. Similarly, while repayments are being made, average monthly repayments both while graduates are in their twenties and over all repayment years are higher for those in higher lifecycle earnings quantiles.

The percentage of net income that is accounted for by repayments the net $\mathrm{RB}$ - ranges from 1.5 to $6.3 \%$; for those in the bottom half of the lifecycle earnings distribution, the maximum net $\mathrm{RB}$ is $6.1 \%$. These compare favourably to the much higher RBs implied by the mortgagetype loan scheme described in Section 4 above. RBs are clearly higher in panels $C$ and $D$, which describe results for schemes with repayments based on total income. However, the loans are also fully repaid more quickly for these ICL versions.

Considering the total amounts repaid, for variations that entail a zero real interest rate, there is no difference across the earnings distribution. However, for the two schemes that entail a positive real rate of interest (Panels A and C), total repayments are lower for higher life-cycle earnings quantiles, because interest payments are lower. However, this apparent regressivity of repayments is reversed when total repayments are discounted by $2 \%$. In this case, the fact that those at lower quantiles repay their loans later in their working lives leads to those repayments being discounted more heavily, and so discounted repayments being progressive. This progressivity of total discounted repayments is also evident in Panels $\mathrm{B}$ and $\mathrm{D}$, which entail zero real interest rates.

Results for male workers, reported in Table 4, show similar results as for women in many respects. However, for all ICL versions, only the bottom $5 \%$ of earners fail to pay off their loans in full, compared to the $10-15 \%$ that applies to women. This is the result of men having steeper age-earnings profiles, so that even those at lower quantiles reach the earnings threshold for enough years to make repayments in full. The fact that the simulated earnings profiles for men are steeper than for women also leads to the RBs for men being higher, lying between $2.9 \%$ and $8.6 \%$ of net income for the quantiles shown. Of course, the faster rate of repayment also leads to men making repayments for fewer years than women. ${ }^{16}$ Once again, total discounted repayments are

\footnotetext{
15 To the extent that students graduate after three years, their loans will be lower than $€ 16,000$ and the number of years of repayment will be correspondingly lower, so these figures should be thought of as the worst case scenario; the RBs faced by graduates under ICLs remain correct.

${ }^{16}$ Note that the number of years of repayment is higher at the median than for the 30th percentile, and the size of the repayments is correspondingly lower. The reason for this apparently anomalous pattern is that the estimated median age-earnings profile is relatively shallow after the repayment threshold of $€ 26,000$ is reached, so the payments made are positive but relatively low during the repayment years.
}

progressive in the sense that they increase as the position in the lifecycle earnings distribution improves.

Tables 3 and 4 apply to those graduates who work in every year and so take no account of two crucial elements that determine ICL repayments: employment and emigration. It is important to note that a year of non-employment or of emigration does not cause a permanent nonrepayment, but rather a delay of one year. Thus, non-employment and temporary emigration reduce the net present value of total repayments.

In implementing the modification of the repayment patterns caused by employment rates of below $100 \%$, we assume that years of nonemployment are experienced randomly; this imposes the assumption that in any year, each graduate has a fixed probability of working given by the sample employment rates obtained from EU-SILC 2006 data shown in Table A2. This is certainly an over-simplification, since a year of non-work is more likely to be experienced by those with lower earnings, and is likely to be correlated with non-participation in subsequent years. However, in the absence of panel data of sufficient length to estimate covariances of employment periods, this is the best that can be achieved.

It is important to note that there is no behavioural content in this analysis - current employment rates are used only to adjust for the proportion of total loans repaid. Since loan repayments reduce net earnings, it is possible that ICL schemes have negative effects on labour supply, which would imply a higher degree of non-repayment than predicted using current participation rates. Such incentive effects are more likely for low-earning graduates and for women. However, since ICL schemes are typically introduced at a national level, the separation of labour supply effects from longer-run trends is difficult empirically.

However, on the above issue, Chapman and Leigh (2009) investigate behavioural effects of the marked discontinuity in net earnings induced by the earnings threshold in the Australian system. They find that graduates subject to loan repayments are indeed more likely to take advantage of work-related tax deductions to restrict their income to ensure that they stay below the threshold. However, although statistically significant, these effects are empirically very small. While this work does not directly test potential labour supply effects, it does suggest very small behavioural responses to the Australian system. Consequently, we regard using current participation rates as estimates of future rates as appropriate.

As discussed in Section 2, emigration is also an important consideration in the Irish context. Although Australia, New Zealand and England have all introduced methods to encourage repayments by emigrating graduates, we assume the worst case scenario - that emigrants make no payments while abroad. Based on the Arslan et al. (2014) figure of $20 \%$ of Irish graduates living abroad cited above, we assume that $10 \%$ emigrate permanently, while another $10 \%$ are abroad in any given year, resulting in a probability of temporary emigration of 0.1 each year. While the effect of living abroad for a year is to delay repayments, a year of permanent emigration necessarily causes lost repayments given our assumption of zero repayments by emigrants. This assumption is a very conservative one. For example, in the UK, the majority of EU students who go back overseas after graduating - and who might reasonably be regarded as 'permanent' emigrants from the UK - do make repayments of their student loans; government figures indicate that repayments were being made as required on about $57 \%$ of the outstanding loan balance. ${ }^{17}$

It is worth noting that we assume that the propensities to emigrate and return migrate by graduates are unaffected by the introduction of an income-contingent loan system. Although this may seem to be a strong assumption, the limited evidence on graduate emigration suggests that economic factors are not very important in such decisions.

\footnotetext{
17 See Department of Business, Innovation and Skills, 2016, Student Loan Repayment for Sustainable Higher Education: Joint Repayment Strategy, paragraph 26.
} 
Table 3

ICL repayments for female employees, selected percentiles of the lifetime earnings distribution, various ICL specifications.

\begin{tabular}{|c|c|c|c|c|c|c|}
\hline & 10th & 20th & 30th & 50th & 70th & 80th \\
\hline \multicolumn{7}{|c|}{ Panel A: $8 \%$ repayment rate on marginal income; $2 \%$ real interest rate when income above $€ 26,000$} \\
\hline$\%$ loan repaid & 9.0 & 100 & 100 & 100 & 100 & 100 \\
\hline \# years payment & 14 & 26 & 17 & 12 & 12 & 11 \\
\hline Age final payment & 55 & 53 & 43 & 36 & 33 & 31 \\
\hline Mean \% net income & 1.5 & 2.7 & 3.5 & 4.3 & 4.3 & 4.4 \\
\hline Mean monthly payment & 35 & 69 & 92 & 127 & 127 & 137 \\
\hline Mean payment, 21-29 & $\mathrm{n} / \mathrm{a}$ & 27 & 51 & 76 & 98 & 132 \\
\hline Total repayments & 5854 & 21,456 & 18,853 & 18,247 & 18,353 & 18,054 \\
\hline Total, $2 \%$ discount & 3099 & 13,126 & 13,388 & 13,929 & 14,782 & 15,077 \\
\hline \multicolumn{7}{|c|}{ All percentiles above the 15th repay in full. } \\
\hline \multicolumn{7}{|c|}{ Panel B: $8 \%$ repayment rate on marginal income; $0 \%$ real interest rate } \\
\hline$\%$ loan repaid & 36.6 & 100 & 100 & 100 & 100 & 100 \\
\hline \# years payment & 14 & 23 & 15 & 11 & 11 & 10 \\
\hline Age final payment & 55 & 50 & 41 & 35 & 32 & 30 \\
\hline Mean \% net income & 1.5 & 2.4 & 3.4 & 4.2 & 4.1 & 4.3 \\
\hline Mean monthly payment & 35 & 58 & 89 & 121 & 121 & 133 \\
\hline Mean payment, $21-29$ & $\mathrm{n} / \mathrm{a}$ & 27 & 51 & 76 & 98 & 118 \\
\hline Total repayments & 5854 & 16,000 & 16,000 & 16,000 & 16,000 & 16,000 \\
\hline Total, $2 \%$ discount & 3099 & 10,293 & 11,619 & 12,348 & 13,027 & 13,206 \\
\hline \multicolumn{7}{|c|}{ All percentiles above the 15 th repay in full. } \\
\hline \multicolumn{7}{|c|}{ Panel C: $2-8 \%$ repayment rate on total income; $2 \%$ real interest rate when income above $€ 26,000$} \\
\hline$\%$ loan repaid & 56.0 & 100 & 100 & 100 & 100 & 100 \\
\hline \# years payment & 14 & 19 & 11 & 9 & 9 & 8 \\
\hline Age final payment & 55 & 46 & 37 & 33 & 30 & 28 \\
\hline Mean \% net income & 3.3 & 3.6 & 5.1 & 5.8 & 5.9 & 6.3 \\
\hline Mean monthly payment & 73 & 84 & 134 & 162 & 163 & 182 \\
\hline Mean payment, 21-29 & $\mathrm{n} / \mathrm{a}$ & 63 & 86 & 124 & 162 & 182 \\
\hline Total repayments & 12,335 & 19,180 & 17,749 & 17,550 & 17,650 & 17,440 \\
\hline Total, $2 \%$ discount & 6868 & 13,126 & 13,388 & 13,929 & 14,782 & 15,077 \\
\hline \multicolumn{7}{|c|}{ All percentiles above the 10th repay in full. } \\
\hline \multicolumn{7}{|c|}{ Panel D: $2-8 \%$ repayment rate on total income; $0 \%$ real interest rate } \\
\hline$\%$ loan repaid & 77.1 & 100 & 100 & 100 & 100 & 100 \\
\hline \# years payment & 14 & 17 & 10 & 8 & 9 & 8 \\
\hline Age final payment & 55 & 44 & 36 & 32 & 30 & 28 \\
\hline Mean \% net income & 3.3 & 3.4 & 5.1 & 6.1 & 5.4 & 5.9 \\
\hline Mean monthly payment & 73 & 78 & 133 & 167 & 148 & 167 \\
\hline Mean payment, 21-29 & $\mathrm{n} / \mathrm{a}$ & 63 & 86 & 124 & 162 & 167 \\
\hline Total repayments & 12,335 & 16,000 & 16,000 & 16,000 & 16,000 & 16,000 \\
\hline Total discounted by $2 \%$ & 6868 & 11,270 & 12,167 & 12,773 & 13,480 & 13,896 \\
\hline
\end{tabular}

For example, Gibson and McKenzie (2011) study the migration and return migration decisions of top students in three Pacific Island nations and conclude that economic incentives play a minor role in determining which of the highly skilled migrate and return and which do not. This suggests that loan repayments that reduce the effective wage rate would not affect the migration or return migration decision.

The results of this analysis are reported in Table 5. The column for the undiscounted repayment rates indicates that total repayment rates remain high, even allowing for non-employment and emigration. The ICL versions that entail positive real interest rates imply repayment rates of 95 and $97 \%$ for schemes with repayments based on total and marginal income respectively; for the schemes with a zero real interest rate, repayments of $83 \%$ and $85 \%$ are predicted. However, because many graduates do not reach the earnings threshold until several years into their working lives, and because both non-employment and temporary emigration entail further delays in repayments, discounted repayment rates are significantly lower, at $63-74 \%$, implying a subsidy of $26-37 \%$ on the student contribution component of government funding. These subsidy estimates are similar to those found by Flannery and O'Donoghue (2011), using different data and ICL scheme designs and a microsimulation approach.

It is important to recall that these estimated subsidy rates are based on the strong assumption that graduates who emigrate - whether permanently or temporarily - make no repayments in the years that they are abroad. If the question of how to encourage repayments by emigrants can be addressed, subsidies will be lower than indicated by the results shown in Table 5; a separate analysis, not reported here, shows that if emigrants repaid fully, subsidy rates would be about 10 percentage points lower.

An overview of the results shown in Tables 3-5 indicates that the schemes that include a non-zero real interest rate element are preferable from the point of view of the government's fiscal position, since the discounted repayments are higher for these schemes; of course, they are less preferred by graduates for the same reason. The slight regressivity of schemes with interest rates - at least in terms of undiscounted repayments - is an unattractive feature of these schemes, although discounted repayments are progressive. However, for all of the ICL schemes modelled, repayments are affordable and lie well below the critical RB threshold of $18 \%$.

\section{Conclusions}

This paper has assessed the feasibility of alternative student loan schemes for the Irish case. This is a highly pertinent exercise for current Irish higher education financing policy, for several reasons. First, additional funding is needed for the higher education system as a result of a severe fiscal crisis. Second, the same fiscal crisis has led to substantial increases in taxes in recent years, which has led to strong political resistance to higher education funding coming from further increases in taxes. Finally, the measures taken during the crisis have been perceived 
Table 4

ICL repayments for male employees, selected percentiles of the lifetime earnings distribution, various ICL specifications.

\begin{tabular}{|c|c|c|c|c|c|c|}
\hline \multicolumn{7}{|c|}{ Panel A: $8 \%$ repayment rate on marginal income; $2 \%$ real interest rate when income above $€ 26,000$} \\
\hline & 10th & 20th & 30th & 50th & 70th & 80th \\
\hline$\%$ loan repaid & 100 & 100 & 100 & 100 & 100 & 100 \\
\hline \# years payment & 21 & 12 & 11 & 13 & 9 & 7 \\
\hline Age final payment & 51 & 40 & 38 & 36 & 29 & 27 \\
\hline Mean \% net income & 3.1 & 4.3 & 4.4 & 4.0 & 5.2 & 6.0 \\
\hline Mean monthly payment & 80 & 127 & 136 & 119 & 162 & 203 \\
\hline Mean payment, $21-29$ & $\mathrm{n} / \mathrm{a}$ & 17 & 43 & 60 & 162 & 203 \\
\hline Total repayments & 20,227 & 18,231 & 17,993 & 18,637 & 17,492 & 17,014 \\
\hline Total discounted by $2 \%$ & 12,369 & 12,868 & 13,126 & 14,208 & 15,077 & 15,077 \\
\hline \multicolumn{7}{|c|}{ All percentiles above the 5 th repay in full } \\
\hline \multicolumn{7}{|c|}{ Panel B: $8 \%$ repayment rate on marginal income; $0 \%$ real interest rate } \\
\hline$\%$ loan repaid & 100 & 100 & 100 & 100 & 100 & 100 \\
\hline \# years payment & 18 & 11 & 10 & 12 & 9 & 7 \\
\hline Age final payment & 48 & 39 & 37 & 35 & 29 & 27 \\
\hline Mean $\%$ net income & 2.9 & 4.2 & 4.4 & 3.8 & 4.8 & 5.7 \\
\hline Mean monthly payment & 74 & 121 & 133 & 111 & 148 & 190 \\
\hline Mean payment, 21-29 & $\mathrm{n} / \mathrm{a}$ & 17 & 43 & 60 & 148 & 190 \\
\hline Total repayments & 16,000 & 16,000 & 16,000 & 16,000 & 16,000 & 16,000 \\
\hline Total discounted by $2 \%$ & 10,103 & 11,417 & 11,770 & 12,340 & 13,878 & 14,229 \\
\hline \multicolumn{7}{|c|}{ All percentiles above the 5 th repay in full } \\
\hline \multicolumn{7}{|c|}{ Panel C: $2-8 \%$ Repayment rate on total income; $2 \%$ real interest rate when income above $€ 26,000$} \\
\hline$\%$ loan repaid & 100 & 100 & 100 & 100 & 100 & 100 \\
\hline \# years payment & 15 & 9 & 8 & 10 & 7 & 5 \\
\hline Age final payment & 45 & 37 & 35 & 33 & 27 & 25 \\
\hline Mean $\%$ net income & 4.3 & 5.8 & 6.3 & 5.4 & 6.9 & 8.6 \\
\hline Mean monthly payment & 104 & 162 & 182 & 149 & 202 & 276 \\
\hline Mean payment, $21-29$ & $\mathrm{n} / \mathrm{a}$ & 48 & 68 & 101 & 202 & 276 \\
\hline Total repayments & 18,693 & 17,533 & 17,442 & 17,910 & 16,966 & 16,588 \\
\hline Total discounted by $2 \%$ & 12,369 & 12,868 & 13,126 & 14,208 & 15,077 & 15,077 \\
\hline \multicolumn{7}{|c|}{ All percentiles above the 5 th repay in full. } \\
\hline \multicolumn{7}{|c|}{ Panel D: $2-8 \%$ repayment rate on total income; $0 \%$ real interest rate } \\
\hline$\%$ loan repaid & 100 & 100 & 100 & 100 & 100 & 100 \\
\hline \# years payment & 14 & 8 & 8 & 9 & 6 & 5 \\
\hline Age final payment & 44 & 36 & 35 & 32 & 26 & 25 \\
\hline Mean \% net income & 4.0 & 6.0 & 5.8 & 5.5 & 7.6 & 8.3 \\
\hline Mean monthly payment & 95 & 167 & 167 & 148 & 222 & 267 \\
\hline Mean payment, $21-29$ & $\mathrm{n} / \mathrm{a}$ & 48 & 68 & 101 & 222 & 267 \\
\hline Total repayments & 16,000 & 16,000 & 16,000 & 16,000 & 16,000 & 16,000 \\
\hline Total discounted by $2 \%$ & 10,775 & 11,804 & 12,096 & 12,787 & 14,265 & 14,565 \\
\hline All percentiles above the & & & & & & \\
\hline
\end{tabular}

Table 5

Proportion of $€ 16,000$ repaid for alternative ICL repayment schemes, accounting for employment and emigration patterns.

\begin{tabular}{lll}
\hline & $0 \%$ discount rate & $2 \%$ discount rate \\
\hline $\begin{array}{c}\text { 8\% repayment of marginal income, } 0 \% \\
\quad \text { real interest rate }\end{array}$ & 0.83 & 0.63 \\
$\begin{array}{c}8 \% \text { repayment of marginal income, } 2 \% \\
\quad \text { real interest rate }\end{array}$ & 0.97 & 0.72 \\
$\begin{array}{c}2-8 \% \text { repayment of total income, 0\% real } \\
\text { interest rate }\end{array}$ & 0.85 & 0.67 \\
$\begin{array}{c}2-8 \% \text { repayment of total income, 2\% real } \\
\text { interest rate }\end{array}$ & 0.95 & 0.74 \\
\hline
\end{tabular}

as affecting younger generations particularly badly, so the importance of loan repayments being affordable is particularly strong.

We illustrate how alternative loan schemes might operate in practice in the Irish case. To do this, we first simulate life-cycle earnings profiles for 19 points across the graduate earnings distribution, separately for men and women, using unconditional quantile regression. Simulations of the time pattern of repayments are then carried out, first for alternative mortgage-type loan schemes with varying repayment terms and loan amounts, followed by four alternative ICL schemes that vary according to their interest rate regime and the basis on which repayments are calculated.
The results for a mortgage-type loan confirm that, as in other countries, RBs are adversely very high for men and women at the bottom of the earnings distribution. Using a threshold of $18 \%$ of gross income as the point at which hardship arises, we see that a substantial proportion - and in some cases a majority - of Irish graduates would be in difficulty with a mortgage-type loan in the early years following the commencement of repayments.

Turning to the alternative ICL schemes, it is found that repayment burdens are modest for all graduates, and particularly for low earners; this of course is the result of ICL scheme design, which sets maximum caps on RBs. We also find that the government subsidy varies substantially according to the design of the scheme that is chosen, with the most important consideration being the choice of interest rate regime. We model a scheme with an interest rate equal to the rate of inflation as the baseline, but rising to a $2 \%$ real rate in years in which the earnings threshold is reached. For this option, the government subsidy is $26 \%$; this figure is not very different to that found for Australia, and a lot lower than is the case for England.

The analysis also highlights the importance of the policy treatment of graduates who emigrate. Hypothetical calculations reveal that encouraging emigrants to repay their student loans will reduce the government subsidy by up to 10 percentage points. One approach to encouraging repayments by emigrants would be to involve the cooperation of other governments in the collection of the debt. However, this may not be politically feasible. Alternatively, as suggested by 
Chapman and Higgins (2013) and now instituted in New Zealand, a system can be designed that puts a legal obligation on a debtor going overseas to repay a minimum amount of their obligation each year in which they are away. The Australian government recently legislated an obligation for ICL debtors to submit payments in line with their incomes outside Australia, but it is too early to judge the success or otherwise of this new arrangement.

The analysis reported here essentially reveals two critical points for the Irish student loan policy debate. The first is that the use of a mortgage-type loan, such as exists in the US and Canada, will be associated with significant repayment difficulties for many graduates, and thus may lead to non-trivial levels of default. The second is that if designed well, an ICL has considerable potential merit in addressing what many would describe as a crisis in Irish higher education. Paying attention to issues of interest rate subsidies and graduate emigration will be critical.

\section{Acknowledgements}

We are grateful to Mary Smyth and Ben Berstock of the Central Statistics Office for facilitating access to the NES data used in our analysis. We thank participants at seminars at the Geary Institute, University College Dublin; Maynooth University; Tongji University, Shanghai; and at the 2016 Irish Economic Association Annual Conference in Galway as well as two anonymous referees of this journal for comments on earlier versions of this paper. We gratefully acknowledge the funding provided by Maynooth University for the conference on Higher Education Funding that initiated this research project. Bruce Chapman also wishes to acknowledge gratefully funding assistance from the Australian Research Council (LP1 102200496). The authors alone are responsible for errors and omissions.

\section{Supplementary materials}

Supplementary material associated with this article can be found, in the online version, at doi:10.1016/j.econedurev.2018.06.002.

\section{Appendix A}

Table A1

Descriptive statistics for estimation sample.

\begin{tabular}{|c|c|c|c|}
\hline Variable and statistic & Males & Females & All \\
\hline Annual earnings: $\quad$ Mean & 64,188 & 45,952 & 53,879 \\
\hline Standard deviation & 42,602 & 24,529 & 34,795 \\
\hline Mean & 38.1 & 36.3 & 37.1 \\
\hline Standard deviation & 8.7 & 8.4 & 8.5 \\
\hline Hours per week: & 36.1 & 33.0 & 34.3 \\
\hline Standard deviation & 9.0 & 10.2 & 9.8 \\
\hline Part-time $\%$ & 4.8 & 14.4 & 10.2 \\
\hline Primary degree $\%$ & 31.8 & 22.6 & 26.6 \\
\hline $\begin{array}{r}\text { Degree plus professional } \\
\text { qualification } \%\end{array}$ & 23.3 & 31.4 & 27.9 \\
\hline $\begin{array}{r}\text { Degree plus postgraduate } \\
\text { certificate or diploma \% }\end{array}$ & 14.0 & 22.7 & 19.0 \\
\hline Postgraduate degree $\%$ & 24.9 & 20.3 & 22.3 \\
\hline $\mathrm{PhD} \%$ & 6.0 & 2.9 & 4.2 \\
\hline Public sector $\%$ & 47.7 & 66.5 & 58.4 \\
\hline Ever lived abroad \% & 28.1 & 28.8 & 28.5 \\
\hline
\end{tabular}

Table A2

Female and male graduate employment rates, EU-SILC 2006.

\begin{tabular}{lll}
\hline Age & Female graduate employment rate & Male graduate employment rate \\
\hline 21 & 0.442 & 0.386 \\
22 & 0.532 & 0.569 \\
23 & 0.677 & 0.6 \\
24 & 0.772 & 0.647 \\
25 & 0.831 & 0.77 \\
26 & 0.787 & 0.826 \\
27 & 0.748 & 0.769 \\
28 & 0.851 & 0.829 \\
29 & 0.865 & 0.849 \\
30 & 0.823 & 0.875 \\
31 & 0.894 & 0.87 \\
32 & 0.845 & 0.88 \\
33 & 0.823 & 0.943 \\
34 & 0.831 & 0.947 \\
35 & 0.82 & 0.958 \\
36 & 0.819 & 0.947 \\
37 & 0.762 & 0.957 \\
38 & 0.765 & 0.94 \\
39 & 0.736 & 0.909
\end{tabular}


Table A2 (continued)

\begin{tabular}{|c|c|c|}
\hline Age & Female graduate employment rate & Male graduate employment rate \\
\hline 40 & 0.753 & 0.88 \\
\hline 41 & 0.837 & 0.871 \\
\hline 42 & 0.83 & 0.927 \\
\hline 43 & 0.846 & 0.91 \\
\hline 44 & 0.861 & 0.935 \\
\hline 45 & 0.821 & 0.909 \\
\hline 46 & 0.872 & 0.92 \\
\hline 47 & 0.861 & 0.908 \\
\hline 48 & 0.834 & 0.871 \\
\hline 49 & 0.808 & 0.888 \\
\hline 50 & 0.826 & 0.91 \\
\hline 51 & 0.832 & 0.915 \\
\hline 52 & 0.837 & 0.883 \\
\hline 53 & 0.828 & 0.887 \\
\hline 54 & 0.793 & 0.889 \\
\hline 55 & 0.791 & 0.917 \\
\hline 56 & 0.761 & 0.838 \\
\hline 57 & 0.707 & 0.812 \\
\hline 58 & 0.635 & 0.744 \\
\hline 59 & 0.575 & 0.736 \\
\hline 60 & 0.581 & 0.581 \\
\hline 61 & 0.456 & 0.558 \\
\hline 62 & 0.521 & 0.619 \\
\hline 63 & 0.387 & 0.518 \\
\hline 64 & 0.306 & 0.573 \\
\hline 64 & 0.265 & 0.364 \\
\hline 66 & 0.111 & 0.222 \\
\hline
\end{tabular}

\section{References}

Amárach Consulting, (2015). Attitudes to higher education: A report prepared for the expert group on future funding for higher education. http://www.hea.ie/sites/ default/files/focus_group_research.pdf.

Arslan, C., Dumont, J.-C., Kone, Z., Moullan, Y., Ozden, C., Parsons, C., et al. (2014). A new profile of migrants in the aftermath of the recent economic crisis. OECD social, employment and migration. OECD Publishing. Working Papers, No. 160 http://dx.doi. org/10.1787/5jxt2t3nnjr5-en.

Barr, N. (2001). Government as piggy-bank. Cambridge: Cambridge University Press.

Baum, S., \& Schwartz, S. (2006). How much debt is too much? Defining benchmarks for manageable student debt. New York: The College Board.

Borjas, G. J. (1985). Assimilation, changes in cohort quality, and the earnings of immigrants. Journal of Labor Economics, Vol. 3(4), 463-489.

Central Statistics Office. (2007). National employment survey 2006. Dublin: Stationery Office.

Chapman, B. (2006). Income contingent loans for higher education: International reforms. In E. Hanushek, \& F. Welch (Vol. Eds.), Handbook of the economics of education: Vol. 2, (pp. 1435-1503). Amsterdam: Elsevier North-Holland.

Chapman, B., \& Higgins, T. (2013). The costs of unpaid higher education contribution scheme debts of graduates working abroad. Australian Economic Review, 46(3), 286-299.

Chapman, B., \& Leigh, A. (2009). Do very high tax rates induce bunching? Implications for the design of income contingent loan schemes. The Economic Record, 85(270), 276-289.

Chapman, B., \& Liu, A. (2013). Repayment Burdens of Student loans of Vietnamese Higher Education. Economics of Education Review, 37, 298-308.

Collins, M. (2016). Earnings and low pay in the Republic of Ireland. Journal of the Statistical and Social Inquiry Society of Ireland, XLV, 146-174.

Conefrey, T., \& Smith, R. (2014). On the slide? Salary scales for new graduates 20042012. Central Bank of Ireland Economic Letters Series, 2014(1).

Crawford, C., Crawford, R., \& Jin, W. (2014). Estimating the public cost of student loans. London: Institute for Fiscal Studies Report No. R94.

Denny, K. (2014). The effect of abolishing university tuition costs: Evidence from Ireland. Labour Economics, 26, 26-33.

Doris, A., O'Neill, D., \& Sweetman, O. (2015). Wage flexibility and the great recession: The response of the Irish labour market. IZA Journal of European Labor Studies, 4, 18.

European Commission. (2013). EU employment and social situation: Quarterly review June 2013. Luxembourg: Publications Office of the European Union.

Expert Group on Future Funding for Higher Education. (2015). The role, value and scale of higher education in Ireland. Consultation Paper 1 https://www.education.ie/en/
The-Education-System/Higher-Education/Higher-Education-Role-Value-and-Scaleof-Higher-Education-in-Ireland-Discussion-Paper-1-.pdf.

Expert Group on Future Funding for Higher Education. (2016). Investing in national ambition: A strategy for funding higher education. Dublin: Department of Education and Skills. http://www.education.ie/en/Publications/Policy-Reports/Investing-inNational-Ambition-A-Strategy-for-Funding-Higher-Education.pdf.

Firpo, S., Fortin, N., \& Lemieux, T. (2009). Unconditional quantile regressions. Econometrica, 77(3), 953-973.

Flannery, D., \& O'Donoghue, C. (2011). The life-cycle impact of alternative higher education finance systems in Ireland. The Economic and Social Review, 42(3), 237-270.

Gibson, J., \& McKenzie, D. (2011). The Microeconomic determinants of emigration and return migration of the best and brightest: Evidence from the Pacific. Journal of Development Economics, 95, 18-29.

HEA. (2008). What do graduates do? The class of 2006. Dublin: Higher Education Authority.

HEA. (2014). What do graduates do? The class of 2013. Dublin: Higher Education Authority.

HEA. (2015). What do graduates do? The class of 2014. Dublin: Higher Education Authority.

HEA. (2017). What do graduates do? The class of 2015. Dublin: Higher Education Authority.

McCoy, S., Calvert, E., Smyth, E., \& Darmody, M. (2009). Study on the costs of participation in higher education. Dublin: Higher Education Authority.

McGuinness, S., Bergin, A., \& Whelan, A. (2015). A comparative time series analysis of overeducation in Europe: Is there a common policy approach? Brighton: University of Brighton. STYLE Working Papers, WP 5.1. CROME http://www.style-research.eu/ publications/working-papers/.

Mooney, O., Patterson, V., O'Connor, M., \& Chantler, A. (2010). A study of progression in Irish higher education. Dublin: Higher Education Authority.

O'Connell, P., Clancy, D., \& McCoy, S. (2006). Who went to college in 2004? A national survey of new entrants to higher education. Dublin: Higher Education Authority.

OECD. (1997). Education at a glance. Paris: Organisation for Economic Cooperation and Development.

OECD. (1998). Education at a glance. Paris: Organisation for Economic Cooperation and Development.

OECD. (2016). Education at a glance. Paris: Organisation for Economic Cooperation and Development.

OECD. (2017). Education at a glance. Paris: Organisation for Economic Cooperation and Development.

Shen, H., \& Ziderman, A. (2009). Student loans repayment and recovery: International comparisons. Higher Education, 57(3), 315-333. 